\title{
SERGEJ ABAŠIN
}

\author{
Die Sartenproblematik in der \\ russischen Geschichtsschreibung \\ des 19. und des ersten Viertels des \\ 20. Jahrhunderts
}


